TAPROBANICA, ISSN 1800-427X. October, 2012. Vol. 04, No. 02: pp. 103-104.

(C) Taprobanica Private Limited, 146, Kendalanda, Homagama, Sri Lanka.

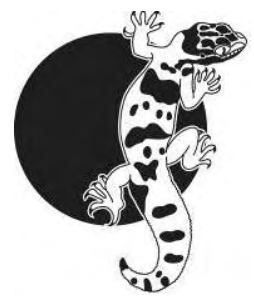

\section{Box turtles in and adjacent to Loktak Lake, Manipur - India}

Manipur is a biodiversity rich state located in the northeastern part of India that borders Myanmar. Situated within the western portion of the IndoBurma biodiversity hotspot, the state has a large number of endemic and endangered species. The state is also prone to habitat destruction due to rapid clearing of forest for shifting cultivation, which is a common practice in the hill districts for agriculture and collection of firewood and timber. In the valley districts, the entire forest areas were converted to agricultural fields leaving only a few remaining green spaces, such as the sacred groves locally known as Umang Lais, small hillocks, and Keibul Lamjao National Park. Loktak Lake (Fig. 1), the largest lake of Manipur, is situated at the southern part of the valley and harbours a rich diversity of both plants and animals. Two important species of Asian box turtles (Cuora mouhotii and $C$. amboinensis), locally known as "thengu" are found in and adjacent to lake. Cuora amboinensis is the most abundant among all chelonians in the state, and Loktak Lake and its adjoining wetlands have been identified as potential habitats of the box turtles (Linthoi \& Sharma, 2009).

Loktak Lake is famous for the presence of socalled "phumdis", a floating landmass (Singh \& Singh, 1994). There are several thousand phumdis floating on the lake, and the largest corresponds to the Keibul Lamjao National Park, the world's only floating national park (Walker, 1994). Cuora mouhotii lives there in the floating landmass as well as on the few islands inside the lake.

The taxonomy of Asian box turtles (genus Cuora, family Geoemydidae) is still in flux. The number of recognized species varies from ten (Fritz \& Havaš, 2007) to 12 (Turtle Taxonomy Working Group, 2011). All species are aquatic and semiaquatic and distributed across Southeast Asia, central to southern China, and northeast India (i.e., Assam and Manipur states; Fritz \& Havaš, 2007; Spinks \& Shaffer, 2007; Linthoi \& Sharma, 2009). Throughout Asia, turtles have been harvested at an unsustainable rate to satisfy demands for food, traditional medicine, and the pet trade. All species of Cuora are listed in the IUCN Red Data Book and nine are currently listed as critically endangered. All species are also listed in Appendix II of the Convention on International Trade in Endangered Species of Wild Fauna and Flora (CITES) (UNEP-WCMC 2005; Spinks \& Shaffer, 2007).

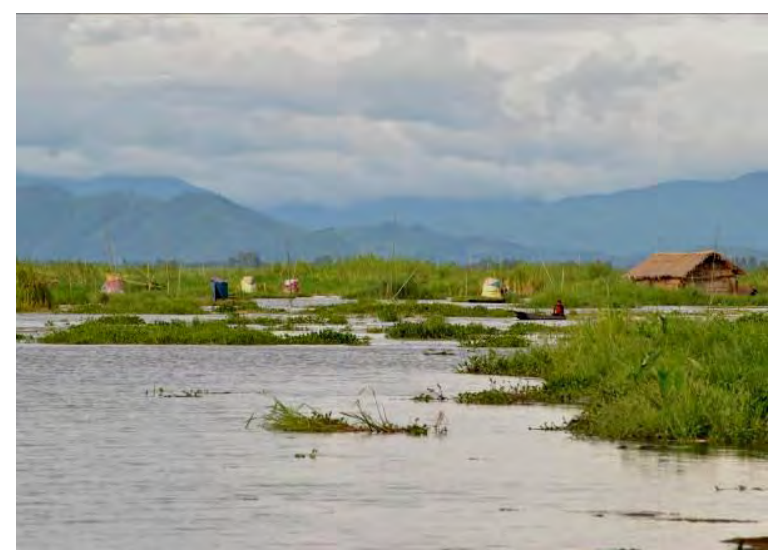

Figure 1: Loktak Lake, Manipur, India

The turtle populations in the state of Manipur are one of the least studied among all the turtles of the country. Major threats to these populations include illegal exploitation for meat and eggs, water pollution, and habitat destruction. Turtles are caught and sold in fish markets (Fig. 2) across the valley towns of Manipur. Though the trade is at low scale, the consumption of meat by the local people is now becoming an immediate threat to the diminishing population of turtles in the lake and adjoining water bodies. Turtles are also used locally in traditional medicinal practices. Submerging of peripheral areas of the lake and a stagnant water body throughout the year due to construction of Ithai Barrage has led to the 
destruction of the natural habitat of these turtles. Pisciculture and agriculture in the low lying submerged areas coupled with extensive use of pesticides has had a great impact on the turtle habitat and their survival.

Selling of turtles in the local markets at low scale is an old tradition followed by local people. However, consumption of turtle meat is not too common. In Manipur, the different clans have a tradition of inhibiting themselves from consuming specific food items of a particular species. The Ningthouja clan of the Meiteis of Manipur considered it a taboo to consume turtle or tortoise meat (Gupta \& Guha, 2002).

Before trade and consumption of turtles increases further, necessary conservation strategies should be framed and implemented for the long term conservation of these two species. Research and conservation practices should be initiated in collaboration with universities, institutes and local NGOs to understand the life cycles, threats, and present population status. Involvement of local communities would play an important role in the protection of the turtles and their natural habitats at a large scale. Increase of awareness about conservation and promotion of research through government and nongovernment agencies would enable the study of the biology, distribution, threats, habitat, and conservation of turtles in Manipur.

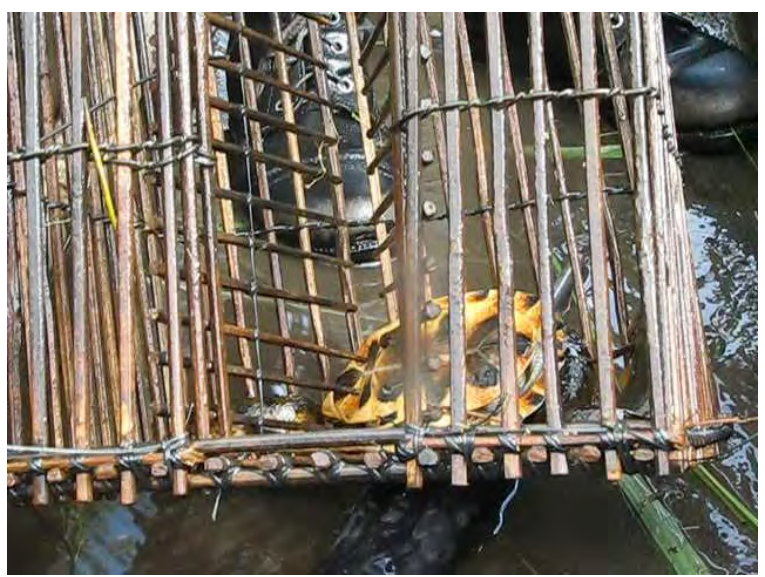

Figure 2: A Cuora amboinensis captured by the local people.

\section{Literature cited}

Fritz, U. and P. Havaš, 2007. Checklist of Chelonians of the World. Vertebrate Zoology, 57 (2): 149-368.

Gupta, A. and K. Guha, 2002. Tradition and conservation in Northeastern India: an ethical analysis. Eubios Journal of Asian and International Bioethics, 12: 15-18.

Linthoi, N. and D. K. Sharma, 2009. Turtles and Tortoises in Manipur. ENVIS Bulletin: Wildlife and Protected Areas, 12 (1). Wildlife Institute of India: 49-52.

Singh, H. T. and R. S. Singh. Ramsar sites of India: Loktak Lake. WWF-India, New Delhi.

Spinks, P. Q. and H. B. Shaffer, 2007. Conservation phylogenetics of the Asian box turtles (Geoemydidae, Cuora): mitochondrial introgression, numts, and inferences from multiple nuclear loci. Conservation Genetics, 8: 641-657.

Turtle Taxonomy Working Group [van Dijk, P. P., J. B. Iverson, H. B. Shaffer, R. Bour and A. G. J. Rhodin], 2011. Turtles of the world, 2011 update: annotated checklist of taxonomy, synonymy, distribution, and conservation status. In: Rhodin, A. G. J., P. C. H. Pritchard, P. P. van Dijk, R. A. Saumure, K. A. Buhlmann, J. B. Iverson and R. A. Mittermeier (eds.). Conservation Biology of Freshwater Turtles and Tortoises: A Compilation Project of the IUCN/SSC Tortoise and Freshwater Turtle Specialist Group. Chelonian Research Monographs No. 5: 000.165-000.242, doi:10.3854/crm.5.000.checklist.v4.2011, http://www.iucn-tftsg.org/cbftt/.

UNEP-WCMC, 2005. UNEP-WCMC Species Database: CITES Listed Species on the World Wide Web (http://www.sea.unep-wcmc.org)

Walker, S. (ed.), 1994. Manipur brow-antlered deer (Cervus eldi eldi) locally known as Sangai: population \& habitat viability assessment, Mysore. Report: August 1994, Coimbatore, India.

Submitted: 11 April 2012, Accepted: 11 June 2012 Sectional Editor: Uwe Fritz

Rajkumar Robindro Singh ${ }^{1,2}$ and Khuraijam Jibankumar Singh ${ }^{\mathbf{1 , 3}}$

${ }^{1}$ North East Centre for Environmental Education \& Research (NECEER), Imphal West 795001, Manipur, India

${ }^{2}$ Email: princerobbin@gmail.com

${ }^{3}$ Email: khuraijam@neceer.org.in 